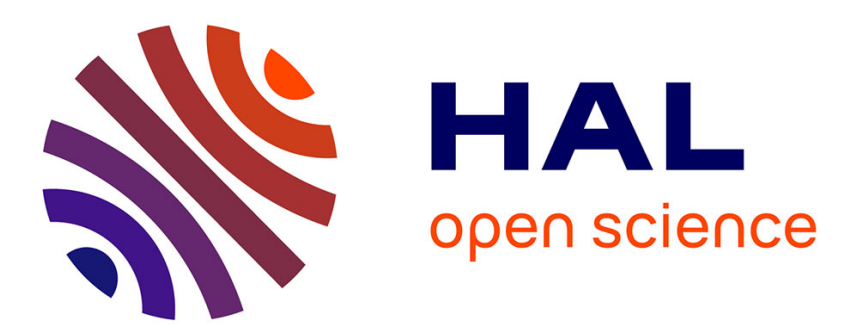

\title{
Cultivation of shiitake mushroom, Lentinula edodes, in several lignocellulosic materials originating from the subtropics
}

Dulce Salmones, Gerardo Mata, Luz Ma. Ramos, Krzystof N. Waliszewski

\section{- To cite this version:}

Dulce Salmones, Gerardo Mata, Luz Ma. Ramos, Krzystof N. Waliszewski. Cultivation of shiitake mushroom, Lentinula edodes, in several lignocellulosic materials originating from the subtropics. Agronomie, 1999, 19 (1), pp.13-19. hal-00885909

\section{HAL Id: hal-00885909 https://hal.science/hal-00885909}

Submitted on 1 Jan 1999

HAL is a multi-disciplinary open access archive for the deposit and dissemination of scientific research documents, whether they are published or not. The documents may come from teaching and research institutions in France or abroad, or from public or private research centers.
L'archive ouverte pluridisciplinaire HAL, est destinée au dépôt et à la diffusion de documents scientifiques de niveau recherche, publiés ou non, émanant des établissements d'enseignement et de recherche français ou étrangers, des laboratoires publics ou privés. 


\title{
Cultivation of shiitake mushroom, Lentinula edodes, in several lignocellulosic materials originating from the subtropics
}

\author{
Dulce Salmones ${ }^{\mathrm{a}}$, Gerardo Mata ${ }^{\mathrm{a}^{*}}$, Luz Ma. Ramos ${ }^{\mathrm{b}}$, Krzystof N. Waliszewski ${ }^{\mathrm{b}}$ \\ ${ }^{a}$ Departamento Hongos, Instituto de Ecología, apartado postal 63, 91000 Xalapa, Ver., México \\ ${ }^{\text {h }}$ Departamento de Ingeniería. Instituto Tecnológico de Veracruz, apartado postal 21, Veracruz, Ver., México
}

(Received 27 October 1998; accepted 15 December 1998)

\begin{abstract}
Mycelial growth of two strains of the mushroom Lentinula edodes (IE-40 and IE-105) was evaluated on barley straw, corn cob, corn stover, rice bran, bracts of pineapple crown, coffee husk, sugarcane bagasse and sugarcane leaves. The last four substrates were chosen for mushroom production essays. A mixture of coffee husks, coffee pulp and sorghum grains was used as spawn. The substrates were sterilised and inoculated, under aseptic conditions, in plastic bags. The bags were incubated at $25^{\circ} \mathrm{C}$ in darkness. There was no development of primordia in the coffee husks. In the other substrates, primordia were observed between 30 and 62 days. Both strains, IE-40 and IE-105, showed their highest production in sugarcane bagasse, with biological efficiencies of $130-133 \%$, followed by $83-98 \%$ in sugarcane leaves and $36-37 \%$ in bracts of pineapple crown. (C Inra/Elsevier, Paris.)
\end{abstract}

\section{Lentinula edodes / shiitake / mushroom cultivation / alternative substrates / Mexico}

Résumé. La culture du shiitake, Lentinula edodes, sur quelques matériaux lignocellulosiques originaires des soustropiques. La croissance mycélienne de deux souches du champignon comestible Lentinula edodes (IE 40 et IE 105) a été testée sur divers substrats : paille d'orge, rafles et paille de maïs, son de riz, bractées de la couronne d'ananas, cosse du grain de café, bagasse et feuilles de la canne à sucre. La meilleure croissance a été obtenue avec les quatre derniers substrats et en conséquence ces substrats ont été utilisés pour des essais de production de champignons. L'inoculum a été produit dans un mélange de cosse du grain café, de pulpe de café et de grains de sorgho. Le substrat, conditionné dans des poches plastiques, a été stérilisé puis ensemencé en conditions aseptiques. Les souches ont été incubées à $25^{\circ} \mathrm{C}$ à l'obscurité. Selon les souches, l'apparition des primordia a varié entre 30 et $62 \mathrm{j}$. Dans le substrat de cosse du grain de café, aucune souche, n'a produit de fructifications. C'est pour la bagasse de canne à sucre que les deux souches ont montré la productivité la plus élevée avec une efficience biologique de $130-133 \%$; pour les feuilles de canne à sucre, elle était de 83-98\% et pour les bractées de la couronne d'ananas, de 36-37\%. (@ Inra/Elsevier, Paris.)

\section{Lentinula edodes / shiitake / culture de champignons / substrat alternatif / Mexique}

Communicated by Gérard Guyot (Avignon, France)

* Correspondence and reprints

E-mail: mata@ecologia.edu.mx 


\section{INTRODUCTION}

The popular Japanese shiitake, Lentinula edodes (Berk.) Pegler, is the second most important mushroom among the species industrially cultivated, with about $17 \%$ of total production, and showing an increase of $110 \%$ between 1990 and 1994 [3]. Traditionally, shiitake has been cultivated on oak $\operatorname{logs}[4,13]$, but recently there is a trend to cultivate it on sterilised or pasteurised substrates in order to increase yield and reduce the time of its culture cycle [7, 17, 27, 28]. Shiitake is produced mainly in China and Japan (more than $93 \%$ ) on oak logs or sawdust but other countries are also initiating production or experimenting with $L$. edodes farming [4]. Interest in shiitake cultivation has recently augmented due mainly to 1 ) high values on the international market, 2) an increase in importation of dried mushrooms by Japan, its main consumer (in 1990 over 2000 metric tons), and 3) antitumoral effects, attributed by various authors to this mushroom [5, $9,25]$.

Mushroom cultivation has received comparatively little attention in most developing countries especially in tropical regions, where millions of tons of lignocellulose-rich wastes are unused [26]. In Mexico most of the studies about shiitake have been directed towards finding alternative substrates, and they include: sawdust from different tree species [21-24], tequila plant bagasse and sugarcane bagasse [8] and coffee pulp [19]. The aim of the present study was to evaluate for shiitake cultivation some abundant lignocellulosics by-products in Mexico and other subtropical regions.

\section{MATERIALS AND METHODS}

\subsection{Strains}

The strains of $L$. edodes are deposited in the Fungi Strain Collection of the Institute of Ecology (Xalapa, Mexico). Strain IE-40 (= LC-35) was donated by Dr S.T. Chang, University of Hong Kong and strain IE-105 (= CS-2) was acquired in Fungi Perfecti (Washington,
USA). The strains were maintained on potato dextrose agar at $25^{\circ} \mathrm{C}$.

\subsection{Mycelial growth on the substrates}

Eight agroindustrial wastes were tested: barley straw, bracts of pineapple crown, coffee husk, corn cob, corn stover, rice bran, sugarcane bagasse and sugarcane leaves. These lignocellulosic materials were chosen due to their easy availability in the tropical and subtropical regions (in Mexico). All materials were fragmented into small pieces of $5 \mathrm{~mm}$ approximately and oven dried $\left(65^{\circ} \mathrm{C}\right)$ for $24 \mathrm{~h}$. Prior to mycelial growth evaluation, samples of $5 \mathrm{~g}$ (by quintuplicate) of dry substrates were hot water-soaked for $12 \mathrm{~h}$, drained and weighted in order to determine their capacity of water absorption. By differences between dry and wet weight, percentage of humidity in the substrates was adjusted to $80 \%$. Then, samples of substrates equivalent to $7 \mathrm{~g}$ of dry weight were placed on $90 \times 15 \mathrm{~mm}$ Petri dishes. Five replicates were prepared by each substrate and sterilised at $121^{\circ} \mathrm{C}$ for $1 \mathrm{~h}$. When the samples cooled down they were inoculated at the centre of Petri dish with an inoculum disc $(0.5 \mathrm{~cm})$ taken from cultures on malt agar. The inoculated substrates were incubated at $25{ }^{\circ} \mathrm{C}$ in darkness. The mycelial size was measured by two diameters of the colony, one taken perpendicularly from the other after 14 days of incubation. The four best substrates for mycelial growth of the strains were chosen for mushroom production essays at pilot plant level.

\subsection{Mushroom production}

\subsubsection{Spawn preparation}

A mixture of coffee husks, coffee pulp and sorghum grains, equivalent in dry weight of 15:15:70\% was used as spawn. Each material was soaked separately in water for $12 \mathrm{~h}$, allowed to drain and then thoroughly mixed. Samples of $150 \mathrm{~g}$ (wet weight) of the mixture were put into plastic bags and sterilised at $121{ }^{\circ} \mathrm{C}$ for $1 \mathrm{~h}$, cotton plugs were sterilised separately. After cooling, the mixture was inoculated with a piece of cultures on malt agar $\left( \pm 1 \mathrm{~cm}^{2}\right)$ and then the bags with cotton plugs were incubated at $25^{\circ} \mathrm{C}$ for approximately 3 weeks.

\subsubsection{Culture conditions}

According to the results of mycelial growth on different substrates, coffee husks, bracts of pineapple crown, 
sugarcane bagasse and leaves were used in order to obtain sporocarps. Sugarcane leaves and bracts of pineapple crown were cut into small lengths of $5 \mathrm{~cm}$ and dried, the former under the sun and the latter in an oven at $50{ }^{\circ} \mathrm{C}$. Sugarcane bagasse and coffee husks did not require fragmentation and they were only dried in the sun. Seven samples $(200 \mathrm{~g})$ of each dry substrate were rehydrated with hot water until reaching $80 \%$ humidity, placed in plastic bags and sterilised at $121^{\circ} \mathrm{C}$ for $1 \mathrm{~h}$, following the method of Auetragul [1], adapted by Guzmán et al. [10]. The bags were cooled down and then inoculated with $150 \mathrm{~g}$ of spawn and incubated at $25^{\circ} \mathrm{C}$ in darkness. When the mycelium had completely covered the substrates, forming a dark coffee coloured crust, the plastic bags were removed and the samples placed in the following environmental conditions: temperature $16-30{ }^{\circ} \mathrm{C}$, relative humidity $82-86 \%$ and natural light $12 \mathrm{~h}$ per day. Fruit body production was expressed as a percentage of biological efficiency (fresh weight mushrooms/dry weight substrates). The fruit bodies were classified into three groups by pileus diameter, following the method of Mata and Guzmán [20]. The groups were, G1: less than $5 \mathrm{~cm}, \mathrm{G} 2: 5-9.9 \mathrm{~cm}$ and $\mathrm{G} 3: 10 \mathrm{~cm}$ and above.

Proximate analysis of substrates before colonisation by mycelia and sporophores collected during the first flush from each substrate, were determined according to the method described by Calvo-Carrillo and Morales de León [2]. Samples were tested by triplicate and the analyses included moisture, ash, crude protein, crude fat, carbohydrates and crude fibre contents.

\subsection{Experimental design and statistical analysis}

The mean and standard deviation of mycelial size at 14 days and harvested sporophores data were calculated, significant differences were estimated using the Tukey's multiple range test with $P<0.05$. During incubation and fruiting, the samples were arranged in a randomised complete plot design.

\section{RESULTS AND DISCUSSION}

\subsection{Mycelial growth on the substrates}

The results of mycelial growth of strains on different substrates are presented in table I. Fourteen
Table I. Comparison of mycelial growth of Lentinula edodes strains (IE-40 and IE-105) on different substrates.

\begin{tabular}{lcc}
\hline Substrates & \multicolumn{2}{c}{$\begin{array}{c}\text { Diameter (mm) of mycelia } \\
\text { 14 days after inoculation }\end{array}$} \\
\cline { 2 - 3 } & IE-40 & IE-105 \\
\hline Barley straw & $5.5 \pm 0.57 \mathrm{e}^{2}$ & $5.2 \pm 0.57 \mathrm{c}$ \\
Bracts of pineapple & & \\
crown & $74.3 \pm 8.45 \mathrm{ab}$ & $50.1 \pm 27.55 \mathrm{~b}$ \\
Coffee husk & $61.6 \pm 17.55 \mathrm{~b}$ & $56.3 \pm 5.35 \mathrm{~b}$ \\
Corn cob & $41.2 \pm 3.76 \mathrm{~cd}$ & $22.4 \pm 3.50 \mathrm{c}$ \\
Corn stover & $24.3 \pm 6.50 \mathrm{de}$ & $26.6 \pm 7.27 \mathrm{c}$ \\
Rice bran & $8.3 \pm 1.76 \mathrm{e}$ & $10.4 \pm 3.62 \mathrm{c}$ \\
Sugarcane bagasse & $89.6 \pm 0.69 \mathrm{a}$ & $89.4 \pm 0.84 \mathrm{a}$ \\
Sugarcane leaves & $59.6 \pm 3.71 \mathrm{bc}$ & $51.8 \pm 4.14 \mathrm{~b}$ \\
\hline
\end{tabular}

' Mean of ten replications.

${ }^{2}$ Different letters in the same column indicate significant differences $(P<0.05)$ according to Tukey's multiple range test.

days after the inoculation, sugarcane bagasse supported the fastest mycelial growth for both strains, the mycelia covered the total diameter of Petri dishes in less time than registered by $L$. edodes growing in Quercus and Carpinus, the common sawdusts utilised for commercial production of shiitake mushroom $[11,18]$. Bracts of pineapple crown, coffee husks and sugarcane leaves also supported good growth. On the contrary, mycelial growth was low on rice bran and barley straw. In general, higher mycelial size was registered for IE-40 than for IE105. According to the statistical analysis, sugarcane bagasse, bracts of pineapple crown, coffee husks and sugarcane leaves were chosen for mushroom production.

\subsection{Mushroom production}

Both strains did not develop mushrooms on coffee husk substrate, although the mycelium showed good growth. Therefore, only the results of three substrates are presented.

Strain IE-40 required 27-32 days of incubation and the primordia appeared between 30 and 59 days, while strain IE-105 required 31-38 days for 
incubation and primordia developed between 47 and 73 days. In both strains, the best substrate colonisation and earliest primordia formation were observed on the sugarcane bagasse (table II). With the exception of the strain IE-105 on sugarcane leaves, the time of primordia appearance was less than those previous studies reported from Mexico [21-23]. However, taking account of the high rate of spawn used in this study (between 12.5 and $15 \%$ depending on the substrate) which was higher than the recommended rate for sterile substrates [14, 15], mycelia colonisation and precocity in primordia formation could be related to number of inoculation points into the substrate.

The number of flushes varied with strains and substrates, the strain IE-40 produced 2-4 flushes and strain IE-105 3-4 flushes; the highest number of flushes was obtained in sugarcane bagasse. Both strains showed their highest biological efficiency on sugarcane bagasse, followed by sugarcane leaves and pineapple crown bracts (table III). There were

Table II. Spawn run and sporophores development time (days after spawning) for two strains of $L$. edodes on three different substrates.

\begin{tabular}{|c|c|c|c|c|c|c|}
\hline \multirow[t]{2}{*}{ Strains } & \multirow[t]{2}{*}{ Substrates $^{1}$} & \multirow{2}{*}{$\begin{array}{l}\text { Time of first } \\
\text { development }\end{array}$} & \multicolumn{4}{|c|}{ Time of flushes } \\
\hline & & & $1 \mathrm{st}$ & 2nd & $3 \mathrm{rd}$ & 4th \\
\hline \multirow{3}{*}{ IE-40 } & SB & $30-32$ & $38-41^{2}$ & $64-66$ & $87-108$ & $117-121$ \\
\hline & SL & $54-57$ & $61-64$ & $79-110$ & $105-133$ & - \\
\hline & $\mathrm{BP}$ & $47-59$ & $54-75$ & $95-97$ & - & - \\
\hline \multicolumn{7}{|l|}{ IE- 105} \\
\hline & $\begin{array}{l}\text { SB } \\
\text { SL }\end{array}$ & $\begin{array}{l}47-57 \\
69-73\end{array}$ & $\begin{array}{l}54-66 \\
75-79\end{array}$ & $\begin{array}{c}86-91 \\
97-106\end{array}$ & $\begin{array}{l}113-135 \\
113-135\end{array}$ & $\begin{array}{c}150-103 \\
146\end{array}$ \\
\hline & $\mathrm{BP}$ & $49-60$ & $61-78$ & $77-79$ & $93-96$ & - \\
\hline
\end{tabular}

I SB: sugarcane bagasse; SL: sugarcane leaves; BP: bracts of pineapple crown.

2 Days of spawn running required for collecting the sporophores.

Table III. Cumulated mushrooms yield and biological efficiency (from seven samples) of two Lentinula edodes strains cultivated on different substrates.

\begin{tabular}{|c|c|c|c|c|c|c|c|}
\hline \multirow[t]{2}{*}{ Strains } & \multirow[t]{2}{*}{ Substrates ${ }^{1}$} & \multicolumn{4}{|c|}{ Fresh weight (total) of mushrooms by flush $(\mathrm{g})$} & \multirow{2}{*}{$\begin{array}{l}\text { Total fresh } \\
\text { weight }(\mathrm{g})\end{array}$} & \multirow[t]{2}{*}{$\mathrm{BE}^{2}$} \\
\hline & & $1^{\mathrm{st}}$ & 2nd & 3 rd & 4 th & & \\
\hline \multicolumn{8}{|l|}{ IE-40 } \\
\hline & SB & 442.4 & 1112.9 & 241.2 & 26.8 & 1823.3 & $130.2 \mathrm{a}^{3}$ \\
\hline & SL & 424.9 & 498.8 & 235.4 & - & 1159.1 & $82.7 \mathrm{~b}$ \\
\hline & $\mathrm{BP}$ & 470.6 & 55.0 & - & - & 525.6 & $37.5 \mathrm{c}$ \\
\hline $10-105$ & SB & 602.6 & 1031.6 & 164.2 & 69.2 & 1867.6 & $133.4 \mathrm{a}$ \\
\hline & SL & 765.9 & 492.9 & 86.2 & 24.3 & 1367.3 & $97.8 \mathrm{~b}$ \\
\hline & BP & 328.1 & 37.4 & 8.7 & - & 374.2 & $36.3 c$ \\
\hline
\end{tabular}

\footnotetext{
I SB: sugarcane bagasse; SL: sugarcane leaves; BP: bracts of pincapple crown.

2 Biological efficiency average $(\%)$ of seven blocks.

${ }^{3}$ Different letters in the same column indicate significative differences $(P<0.05)$ according to Tukey's multiple range test.
} 
Table IV. Proximate composition of Lentinula edodes sporophores cultivated on different substrates.

\begin{tabular}{lcccccc}
\hline & \multicolumn{3}{c}{ Strain IE-40 } & \multicolumn{3}{c}{ Strain IE-105 } \\
\cline { 2 - 7 } Composition & SB & SL & BP & SB & SL & BP \\
\hline Moisture & $89.2^{1,2}$ & 87.3 & 83.8 & 92.3 & 88.3 & 83.9 \\
Protein crude (N x 4.38) & 13.8 & 14.4 & 14.0 & 13.1 & 14.4 & 14.0 \\
Fat crude & 1.0 & 0.9 & 0.5 & 0.9 & 0.7 & 0.5 \\
Carbohydrates & 73.0 & 78.2 & 78.8 & 78.9 & 78.5 & 78.5 \\
Ash & 6.2 & 6.5 & 6.7 & 7.1 & 6.4 & 7.0 \\
\hline
\end{tabular}

${ }^{1}$ All data are presented as percentage of dry weight, except moisture (percentage of fresh weight).

${ }^{2}$ Mean of three replicates.

SB: sugarcane bagasse; SL: sugarcane leaves; BP: bracts of pineapple crown.

significant differences in mushroom production between substrates, but there was no difference between the strains. It is important to state that the biological efficiencies registered on sugarcane bagasse and leaves were higher than those previously reported for Carpinus and Quercus sawdust, tequila maguey bagasse and coffee pulp $[8,19$, 21-24].

With reference to basidiome size, the predominant group in the strain IE-40 grown on sugarcane bagasse and sugarcane leaves was $\mathrm{G}_{2}(57$ and $63 \%$ of total fruiting bodies harvested, respectively) and $\mathrm{G}_{3}$ in pineapple crown bracts $(45 \%)$. In strain IE$105, \mathrm{G}_{2}$ was the main group in sugarcane bagasse and pineapple crown bracts ( 41 and $53 \%$ ) and $\mathrm{G}_{3}$ in sugarcane leaves. Therefore, nearly $75 \%$ of the mushroom production presented pileus with a diameter of $5-10 \mathrm{~cm}$.

The average values of proximate composition of sporophores growing on different substrates were similar and fluctuated between: 83.8 and $92.3 \%$ of moisture, 13.1 and $14.4 \%$ (dry weight) of crude protein, 0.5 and $1 \%$ of crude fat, 73 and $78.9 \%$ of carbohydrates and 7.4 and $12 \%$ of crude fibre (table IV); therefore it confirmed that $L$. edodes is an appropriate source of protein that can be used as complementary in the daily diet. The values registered agree with Crisan and Sands [6]; however, the fluctuations in the percentages depend more on the analytical process and precision of tests, than the proximate composition of the fruiting bodies.
Table V. Proximate and chemical composition of lignocellulose materials used.

Proximate composition

\begin{tabular}{lcccc}
\hline & CH & BP & SL & SB \\
\hline Moisture & $9.3^{1,2}$ & 11.1 & 8.6 & 5.6 \\
Crude protein & 5.6 & 8.7 & 2.1 & 2.0 \\
Carbohydrates & 92.6 & 81.3 & 85.5 & 93.4 \\
Crude fat & 0.8 & 2 & 0.3 & 1.2 \\
Crude fiber & 59 & 25.2 & 39 & 36 \\
Ash & 1 & 8 & 12.1 & 3.4 \\
\hline
\end{tabular}

Chemical composition

\begin{tabular}{lcccc}
\hline Nitrogen & $0.9^{3}$ & 1.4 & 0.3 & 0.3 \\
Carbon & $53.5^{3}$ & 51.3 & 44.6 & 51.1 \\
C/N ratio & 59.4 & 36.6 & 131.1 & 159.6 \\
$\mathrm{pH}$ & 5.6 & 6.4 & 6.0 & 4.5 \\
\hline
\end{tabular}

${ }^{1}$ All data are presented as percentage of dry weight, except moisture (percentage of fresh weight).

2 Mean of three samples.

${ }^{3}$ Percentage of dry weight.

$\mathrm{CH}$ : coffee huks; BP: bracts of pineapple crown; SL: sugarcane leaves; SB: sugarcane bagasse.

On the other hand, by comparing the proximal composition and $\mathrm{pH}$ of the substrates with the yield of the strains (table $V$ ), sugarcane bagasse and sugarcane leaves appeared as the most adequate for shiitake cultivation, since their $\mathrm{C} / \mathrm{N}$ ratios agree with the recommended values [16]. The bracts of pineapple crown registered a high content of nitrogen and 
$\mathrm{pH}$ near neutrality. In addition, the open physical structure of this residues, cannot provide support for the mycelium and affect the normal development of the fructification. In reference to coffee husks, although the chemical composition was appropriate for $L$. edodes cultivation, the presence of some phenolic compounds (not determined in this study) could be detrimental to the formation and development of the fructifications. On coffee husks both strains showed a good mycelial colonisation; however, this substrate was very susceptible to drying, which affected sporophore formation.

The present data show that both sugarcane bagasse and sugarcane leaves are potential substrates for shiitake cultivation, since the strains studied presented the highest production of sporophores in these materials. In addition, the utilisation of these residues offers the following advantages: 1) alternative uses of abundant lignocellulosic wastes in Mexico where approximately 18 million tons are produced annually [12], and also in other tropical or subtropical areas; 2) increased profits from sugarcane cultivation, since two of its by-products would have additional uses; and 3 ) reduction in the cropping cycle of shiitake in comparison to other forest wastes products. However, it is necessary to carry out a specific study to compare shiitake production on sugar cane wastes and wood sawdust, using the same culture conditions.

\section{REFERENCES}

[1] Auetragul A., The highest aspects for cultivating oak mushroom Lentinus edodes in plastic bags, Mush. News. Tropics 5 (1984) 11-15.

[2] Calvo-Carrillo C., Morales de León J., Manual de técnicas de laboratorio para el análisis de alimentos, Inst. Nal. Nutrición S. Zubirán, Mexico City, 1988.

[3] Chang S.T., Mushroom research and development - equality and mutual benefit, in: Royse D.J. (Ed.), Mushroom Biology and Mushroom Products, The Pennsylvania State University Press, University Park, 1996, pp. 1-10.

[4] Chang S.T., Miles, P.G., Edible Mushroom and their Cultivation, CRC Press, Boca Raton, Fl, USA, 1989.
[5] Chihara G., Medicinal aspects of lentinan isolated from $L$. edodes (Berk.) Sing., in: Chang S.T., Buswell J.A., Chiu S.W. (Eds.), Mushroom Biology and Mushroom Products, The Chinese University Press, Hong Kong, 1993, pp. 261-266.

[6] Crisan E.V., Sands A., Nutritional value, in: Chang S.T., Hayes W.A. (Eds.), The Biology and Cultivation of Edible Mushroom, Academic Press, New York, 1978, pp. 137-168.

[7] Delpech P., Olivier J.M., Cultivation of shiitake on straw based pasteurized substrates, Mushroom Sci. 13 (1991) 523-528.

[8] Fausto Guerra S, Cultivo del hongo de encino (Lentinus spp.) sobre una mezcla de bagazo de maguey tequilero y de caña de azúcar, thesis, Faculty of Biological Sciences, University of Guadalajara, Guadalajara, Mexico, 1994.

[9] Flyn V.T., Shiitake cause of longevity?, Mushroom Sci. 13 (1991) 345-364.

[10] Guzmán G., Mata G., Salmones D., SotoVelazco C., Guzmán-Dávalos L., El cultivo de los hongos comestibles, Instituto Politécnico Nacional, Mexico City, 1993.

[11] Han Y.H., Ueng W.T., Cheng L.C., Cheng S., Physiology and ecology of Lentinus edodes (Berk.) Sing., Mushroom Sci. 11 (1981) 623-658.

[12] INEGI, Anuario estadístico 1993, Inst. Natl. Geogr. Est. Inf., Mexico City, 1995.

[13] Ito T., Cultivation of Lentinus edodes, in: Chang S.T., Hayes W.A., (Eds.), The Biology and Cultivation of Edible Mushroom, Academic Press, New York. 1978, pp. $461-473$.

[14] Jong S.C., Commercial cultivation of the shiitake mushroom on supplemented sawdust, Mushroom J. Tropics 9 (1989) 89-98.

[15] Laborde J., A glance at the shiitake production for 1991, Mushroom Information 71 (11) (1991) 4-15.

[16] Leatham G.F., Leonard T.J., Biology and physiology of shiitake mushroom cultivation, in: Shiitake Mushrooms: A national symposium and trade show,. The center for alternative plant and animal products, University of Minnesota, St Paul, 1989.

[17] Levanon D., Rostchild N., Danai O., Masaphy S., Bulk treatment of substrate for the cultivation of shiitake mushroom, Bioresour. Technol. 45 (1993) 63-64.

[18] Mata G., The effect of substrate fermentation on the vegetative growth of Lentinus boryanus and L. edodes, Mushroom. Res. 1 (1992) 53-55. 
[19] Mata G., Gaitán-Hernández R., Avances en el cultivo del shiitake en pulpa de café, Rev. Iberoam. Micol. 11 (1994) 90-91.

[20] Mata G., Guzmán G., Cultivation of Lentinus boryanus in wood shavings in Mexico, Cryptogam. Bot. 4 (1993) 47-49.

[21] Mata G., Salmones D., Guzmán G., Cultivo del shiitake japonés, Lentinus edodes, en bolsas con viruta de madera, Rev. Mex. Micol. 6 (1990) 245-251.

[22] Morales P., Martínez-Carrera D., Cultivo de Lentinula edodes en México, Micol. Neotrop. Apl. 3 (1990) 13-17.

[23] Morales P., Martínez-Carrera D., Bursera sawdust as a substrate for shiitake cultivation, Micol. Neotrop. Apl. 4 (1991) 41-47.
[24] Morales P., Martínez-Carrera D., MartínezSánchez W., Cultivo del shiitake sobre diversos sustratos en México, Micol. Neotrop. Appl. 4 (1991) 75-81.

[25] Mori K., Thakehara M., Antitumor action of fruit bodies of edible mushroom orally administered to mice, Mushroom Sci. 12 (1989) 661-670.

[26] Oei P., Some aspects of mushroom cultivation in developing countries, Mushroom Sci. 13 (1991) 777-780.

[27] Przybylowics P., Donoghue J., Shiitake Growers Handbook. The Art and Science of Mushroom Cultivation, Kendall/Hunt Publ. Co., Dubuque, 1988.

[28] Royse D.J., Schisler L.C., Diehle D.A., Shiitake mushroom. Consumption, production and cultivation, Interdisc. Sci. Rev. 10 (1985) 329-335. 